DOI: https://doi.org/10.34069/AI/2021.47.11.4

How to Cite:

Tarasova, H., Kondrashova, L., Chuvasova, N., Kondrashov, M., \& Tsikh, H. (2021). A combination of forecasting internal and external crises in managing the development of educational institution. Amazonia Investiga, 10(47), 35-46. https://doi.org/10.34069/AI/2021.47.11.4

\title{
A combination of forecasting internal and external crises in managing the development of educational institution
}

\section{СКВОЗНЫЕ ТЕХНОЛОГИИ В ОБРАЗОВАНИИ}

Received: September 15, 2021

Accepted: November 2, 2021

Written by:

Hanna Tarasova ${ }^{14}$

https://orcid.org/0000-0002-5476-9881

Lidiya Kondrashova ${ }^{15}$

https://orcid.org/0000-0002-8876-7294

Nataliia Chuvasova ${ }^{16}$

https://orcid.org/0000-0001-7636-6277

Mykola Kondrashov ${ }^{17}$

https://orcid.org/0000-0002-3411-2209

Halyna Tsikh ${ }^{18}$

https://orcid.org/0000-0002-5049-3814

\begin{abstract}
The article states that management requires forecasting of internal and external crises, timely preparation for which provides the educational institution, as a subject of market relations, competitive advantages and opportunities for development. To solve this problem, an approach to forecasting crisis phenomena in the management of the educational institution has been developed, which takes into account the peculiarities of external and internal crises, is based on formalizing the forecasting process of various components and provides grounds for using forecasts for development.
\end{abstract}

Keywords: forecasting, crisis phenomena, management, development, educational institution, models.

\section{Introduction}

Vital elements of educational institutions fit into the perspective of open systems. The environment consists of a huge number of social, economic and political institutions. The

\section{Аннотація}

У статті зазначається, що управління вимагає прогнозування внутрішніх та зовнішніх криз, своєчасна підготовка до яких надає навчальному закладу, як суб' єкту ринкових відносин, конкурентні переваги та можливості для розвитку. Для вирішення цієї проблеми розроблено підхід до прогнозування кризових явищ в управлінні навчальним закладом, який враховує особливості зовнішньої та внутрішньої криз, базується на формалізації процесу прогнозування різних компонентів та дає підстави для використання прогнозів для розвитку.

Ключові слова: прогнозування, кризові явища, менеджмент, розвиток, навчальний заклад, моделі.

transformation process consists of interacting subsystems that convert the input product into the output: the human-culture subsystem (introduces informally set expectations and norms); strategic

\footnotetext{
${ }^{14}$ Doctor of Economics,Associate Professor of the Department of Economics, Bogdan Khmelnitsky Melitopol State Pedagogical University, Melitopol, Ukraine.

${ }^{15}$ Doctor of Economics,Professor of the Department of Economics, Bohdan Khmenlnytsky National University, Cherkasy, Ukraine.

${ }^{16} \mathrm{PhD}$, Associate Professor of the Department of Economics, State Pedagogical University, KryvyiRih, Ukraine.

${ }^{17} \mathrm{PhD}$, Associate Professor of the Department of Economics, Bohdan Khmenlnytsky National University, Cherkasy, Ukraine.

${ }^{18} \mathrm{PhD}$, Associate Professor, Dean of the Faculty of Economics and Management, Department of Economics and Finance, Ternopil Ivan Puluj National Technical University, Ternopil, Ukraine.
} 
subsystem (generates information on opportunities and problems in the short and long term); technological subsystem (provides the activities of all structures of the educational process); control subsystem (combination and direction of these subsystems). The initial product consists of knowledge, change of position, values, acquisition of professional and other skills, critical thinking, changes in behavior and so on.

The structure and content of the management of educational institutions are influenced by such factors as: the situation on the labor market; innovative economic development; increasing requirements for the level of qualification of the workforce; needs of consumers of educational services; reduction of budget funding of these institutions; growth of openness and democracy of society, etc.

The modern educational system in Ukraine is represented by preschool, general secondary, vocational, higher and postgraduate education (postgraduate and doctoral). The emergence of commercial relations in education, the formation of a network of private educational institutions led to the formation of the market of educational services as a system of commodity-money relations between the subjects of the educational process to achieve a goal that operates on the principles of entrepreneurship and commodity production.

The modern university is a multifaceted social institution: it is a scientific and educational center and at the same time it is an independent economic entity (Grishchenko, 2014). The main feature of the management model of the educational institution as a subject of market relations is the constant adaptation to the dynamic external environment.

The biggest problem of current educational institutions is the lack of practice of mediumterm and long-term development forecasting. Expert assessments, most of which do not use economic-mathematical and statistical methods, have a sufficiently large range of errors and are not scientific. As a result, heads of educational institutions either abandon strategic management altogether (primarily forecasting), or switch to manual management to achieve current goals.

Ensuring the timeliness and accuracy of forecasting of crisis phenomena is one of the most difficult tasks in managing the development of an educational institution as a subject of market relations. Timely detection of the crisis gives the company competitive advantages and additional opportunities, which gives grounds to reduce unproductive costs, promotes intensive development of the educational institution, search for adequate economic and financial tools, creating a management system that will ensure effective action to increase and efficient use of educational resources. increasing competition.

The aim of the article is to develop an approach to forecasting crisis phenomena in the management of an educational institution, which will take into account the features of external and internal crises.

Forecasting of indicators-indicators of the internal crisis of an industrial enterprise is proposed to be carried out by combining simulation modeling and regression-correlation modeling. This makes it possible to take into account both the trends that exist in the development of the educational institution as a subject of market relations, and the change in life cycles and educational services that it offers.

\section{Theoretical Framework or Literature Review}

Quite a lot of scientific work is devoted to the impact of crises and related risks in managing the development of educational institutions, these include the research of (Floricel\&Ibanescu, 2008; Das\&Teng, 1999; Huber, 2011; Huber\&Rothstein, 2013; Raban\&Turner, 2006) who made an attempt to study the process of identifying university risks.

Tarasovaet al., (2019)offers to adapt to sudden changes in the external economic environment or changes in the trajectory of activity. The disadvantage of the approach is the generality of the proposed recommendations without specifying methods for identifying key areas and quantifying the results of development of educational institutions as subjects of market relations (Nelli, etc., 2020). It has been demonstrated that the innovative activity of a modern university is associated with different kinds of uncertainties and risks. Under such circumstances, the management of a higher education institution should make a decision to develop a risk management infrastructure and a detailed risk register, taking into account the actions aimed at reducing the probability of risks and their consequences.

A strategy for creating a system of internal quality assurance in higher education in Ukrainian universities has been developed. It can be implemented by identifying strengths and 


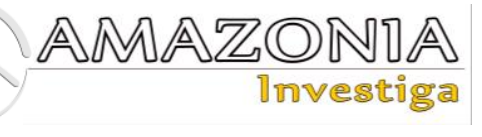

weaknesses, opportunities and threats (Aleksandrova et al., 2019) strategy aimed at sustainable development in universities (Holm et al., 2015).

Any crisis can contribute to the development of an educational institution.

I. Lukmanova and N. Yaskova (2016) believe that the shocks of crises of any national economy as a whole contribute to the development of companies, provided that they make full use of all visible and hidden opportunities, opportunities that fully develop the potential for cost-effective transformation internal and external environment (Lukmanova \& Yaskova, 2016).

Ineffective risk assessment can increase the likelihood of prolonged, severe recessions (Espinosa-Vega\&Russell, 2020).

Aimin Wang and Tyronestudy and Pitsis offers crisis orientation and awareness of the crisis as outstanding precursors to better crisis prediction (Wang, etc., 2020).

The development of an educational institution as a subject of market relations in the conditions of crisis is possible under the condition of early warning about it, for use of competitive advantages and timely application of anti-crisis measures.

Jianxiong Lin (2021) provided a comprehensive built-In systems analysis of early warning systems and their development and use in various environments, where the role of early warning systems in forecasting and detecting adverse events, especially in business and economics, was studied. This study has contributed to the existing literature by systematically analyzing the development and use of early warning systems to predict major and problematic developments in economic development (Lin, 2021).

Long Zhang and Lihong Wang (2016) propose an early warning system, by building which market participants can carry out dynamic monitoring at different stages of business management to understand the risk before crises, to take certain actions during and after crises, (Zhang \& Wang, 2016).

Depending on the source of the crisis, the forecasting of internal and external crises differs. Internal crises are caused by mistakes in the management of educational institutions as a subject of market relations or are the result of natural changes in the stages of their life cycle.

However, the results of research by Jakob de Haan, etc., (2020) show that low levels of liquid assets and domestic financial liabilities, high levels of external liabilities and high increases in financial leverage are leading indicators of the internal crisis (Haan et al., 2020).

Forecasting the internal crises of market participants is a fairly popular research topic, but for the most part they address financial crises and represent various improvements to the Altman model (1967). There are also studies of the causes of internal crises in enterprises and proposals for their forecasting, among the current studies on forecasting internal crises in enterprises should be noted carried out by T. Kulakovskaya (2014) analysis of methods and models for diagnosing critical condition of the enterprise. in crisis and bankruptcy forecasting models. At the same time, it was concluded that all popular models ignore or insufficiently use the indicators of business activity of the enterprise, and the main attention is paid to financial stability. Also, the common models do not take into account the specifics of the functioning of universities and other educational institutions, as well as the peculiarities of the national economy. These findings confirm the relevance of developing crisis forecasting methods for educational institutions as subjects of market relations, which would take into account the above features and provide an opportunity to predict not only financial crises and probabilities of bankruptcy, but also business crises, which are prerequisites for financial crises.

The analysis of approaches to the diagnosis of financial insolvency of the enterprise and their ranking in terms of prognostic ability was carried out in the work of O. Vasiliev and V. Goy (2016). It was concluded that the greatest prognostic ability have methods based on regression and discriminant analysis, the average - rating, criterion and coefficient analysis, and the lowest - analog and regulatory approaches. It is concluded that the most appropriate is to use a hybrid approach with the analysis of the causal links of early bankruptcy. It is claimed that this makes it possible to identify imbalances in the organizational and economic structure of the enterprise and to identify the deterioration of both financial and non-financial indicators. But how exactly it is proposed to analyze nonfinancial indicators in this study is not disclosed. 
Thus, like other approaches, the main focus of O. Vasiliev and V. Goy (2016) is on predicting bankruptcy, while other types of crises have been ignored.

V. Zhyvotenko (2014) proposes crisis forecasting through the construction of a system of indicators of the development of crisis phenomena at the enterprise, and the main cause of the crisis at the enterprise is considered to be the conflict between goals. As indicators V. Zhyvotenko proposes to use the ratio between current liabilities and current assets, long-term liabilities and equity, long-term liabilities and non-current assets. It is believed that this system of indicators ensures the economic security of the enterprise. But it should be noted that all the established indicators belong to the financial sphere, ie, forecasting the crisis with their use is possible only in the final stages of the crisis and does not allow early diagnosis.

Thus, most researchers consider the internal crisis of the subjects of market relations only as a threat to its financial condition and the likelihood of bankruptcy. But, in most cases, the financial crisis is only a consequence of crises of other types, such as personnel, technology, logistics, and so on.

External crises can be the result of gradual development or qualitative leaps. With the gradual emergence of the crisis, the external environment for a long time shows a tendency to deteriorate important for educational institutions, as subjects of market relations, indicators. The crisis due to qualitative jumps occurs relatively instantly, without a gradual deterioration. Predicting such jumps is possible only if scientific and innovative progress is taken into account.

The prediction of external crises that affect the subjects of market relations has been carried out by researchers in various aspects.

Thus, a universal mechanism for predicting crisis phenomena of socio-economic nature is proposed in the work of S. Belay (2015), who consider it necessary to combine the following forecasting methods: adaptive forecasting models, moving average method, exponential smoothing method and linear model Brown. The results of forecasting in suggest to collect in the scenario of crisis situations that may arise in Ukraine. But it should be noted that the mechanism does not have a list of what indicators or indicators need to be predicted to identify crisis phenomena. In addition, forecasting based on time alone is questionable, ignoring the influence of economic agents and the world market.

Predicting external crises due to cyclicality, long Kondratiev waves, etc. is quite common. Thus, in the study of L. Sapayeva (2013) the main factor of global crises is considered to be demographic cycles, which is most important for the functioning of educational institutions in general. However, not enough attention is paid to forecasting exactly how these cycles affect the Ukrainian economy.

Similarly, the forecasting of crisis phenomena by taking into account long waves is proposed to be carried out in the study by N. Stepaniuk (2013), which analyzes the main approaches to forecasting crisis phenomena and identifies the causes of crises in Ukraine. To forecast financial and economic crises for educational institutions in the country, it is proposed to take into account the following indicators (Makarenko, 2008; Stepaniuk, 2013):reduction of the number of workers;reduction of wages;mergers and acquisitions of universities and other educational institutions.

But this promising idea has not been brought to the level of a specific model or method of calculating the probability and strength of the crisis, taking into account the characteristics of Ukrainian educational institutions.

N. Orlovskaya (2012) proposes to predict crises by analyzing several types of short and long economic cycles. She believes that the coincidence of the peaks of several cycles gives a fairly reliable forecast of general economic crises. For analysis N. Orlovskaya (2012)proposes to use the economic cycles of Zhuglyar, Kuznets, Kondratiev and Kitchin. Among the advantages of this approach should be noted the stated ability to predict crises due to changes in technological structure, which is taken into account by the cycles of Kitchin and Juglar. But it should be noted that not all global crises coincide with economic cycles. In addition, no specific tools have been proposed to identify these cycles in Ukraine.

Among the promising approaches should also be noted the model of forecasting the crisis in the economy of Ukraine, in which O. Shulgina (2011) tried to calculate the relationship between a set of macroeconomic indicators and the onset of the crisis. Among the indicators related to the Ukrainian crises were domestic public debt, external public debt, the budget deficit, and the 


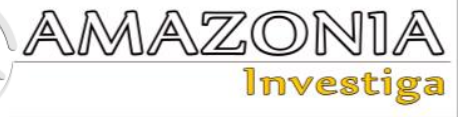

industrial production index. But, like other approaches, it does not take into account the specifics of the external crisis of educational institutions as subjects of market relations.

Thus, in predicting general economic crises, domestic researchers used a system of indicators or analysis of economic cycles. But none of the proposed methods took into account the relationship between the general crisis and the crisis of the educational institution as a subject of market relations.

\section{Methodology}

The development of universities and other educational institutions as subjects of market relations is influenced by external and internal factors. External causes include changes in the external environment of the educational institution that are directly related to its activities. They need to be adequately responded to, providing adequate resilience. Internal sources of development are contained in the school itself and are associated with the contradictions between the "old" and "new" elements functions, structures, individual employees, the struggle between motivating and limiting forces. It is impossible to draw conclusions and propose effective measures for the future development of an educational institution without prior detailed analysis of the environment of educational organizations.

Thus, crisis forecasting for educational institutions consists of two directions forecasting external crises, how they affect the institution, and forecasting internal crises due to the life cycles of the educational institution, as a subject of market relations.

To forecast internal crises in the educational institution, it is proposed to create a system of indicators, depending on the forecasts of deterioration or improvement of which the probability of a crisis is estimated. The system of indicators is based on the principles of building a balanced system of indicators taking into account the peculiarities of Ukrainian educational institutions, first of all, universities.

In addition, forecasting crises that may arise due to bottlenecks requires the inclusion of indicators that characterize the effectiveness of processes: expansion of educational programs; modernization of the educational process; updating educational services; personnel management.

All this led to the choice of indicators to predict the internal crisis of the educational institution as a subject of market relations, which are combined into the following groups: educational process; staffing; finances.

These groups differ from the classical groups adopted for a balanced scorecard because they are needed to predict only internal crises. Therefore, for example, such groups as the "market" in the current aspect do not make sense, because it is a source of external crises. In addition, in contrast to the classical balanced scorecard, the task of the scorecard is to predict the crisis in educational institutions as subjects of market relations, rather than performance management.

The group of indicators "Staffing" is proposed to include characteristics that reflect the qualifications and staffing:staff qualification forecast;staffing forecast;labor cost forecast.

Finally, the group of indicators "Finance" is proposed to include characteristics that characterize the crisis on the part of financial security: liquidity forecast; forecast of thecost of borrowed capital; profitability forecast.

Forecasting of indicators-indicators of the internal crisis of an industrial enterprise is proposed to be carried out by combining simulation modeling and regression-correlation modeling. This makes it possible to take into account both the trends that exist in the development of the educational institution as a subject of market relations, and the change in life cycles and educational services that it offers.

In addition, forecasts of exogenous factors provided by authoritative sources can be used in this type of forecasting (Prokopenko, 2015). This makes it possible to take into account bottlenecks in the functioning of the school system. The relationship between the forecasts of indicators of the internal crisis of the educational institution and endogenous and exogenous sources are shown in Table. 1. 
Table 1.

The relationship between the forecasts of indicators of the internal crisis of the educational institution and endogenous and exogenous sources.

\begin{tabular}{|c|c|c|}
\hline Indicator & Endogenous sources & Exogenous sources \\
\hline Equipment wear & $\begin{array}{l}\text { Plan for modernization of technical } \\
\text { support of the educational process }\end{array}$ & - \\
\hline $\begin{array}{l}\text { The amount of work of the teaching } \\
\text { staff }\end{array}$ & Curriculum & - \\
\hline $\begin{array}{l}\text { Losses and lack of quality of the } \\
\text { educational process }\end{array}$ & $\begin{array}{l}\text { Quality management plan of the } \\
\text { educational process }\end{array}$ & - \\
\hline Qualification of staff & $\begin{array}{l}\text { Staff structure, staff turnover } \\
\text { indicators, qualifications }\end{array}$ & $\begin{array}{l}\text { Demographic } \\
\text { forecasts }\end{array}$ \\
\hline Staffing & $\begin{array}{l}\text { Indicators of staff turnover, } \\
\text { qualifications, age of staff }\end{array}$ & $\begin{array}{l}\text { Demographic } \\
\text { forecasts }\end{array}$ \\
\hline The cost of staffing & Financial plan & $\begin{array}{l}\text { Demographic } \\
\text { forecasts, migration } \\
\text { policy of } \\
\text { neighboring } \\
\text { countries }\end{array}$ \\
\hline Liquidity & Financial plan & - \\
\hline The cost of borrowed capital & Financial plan & Inflation forecast \\
\hline Profitability & Financial plan & $\begin{array}{l}\text { Exchange rate } \\
\text { forecast }\end{array}$ \\
\hline
\end{tabular}

Source: own research

That is, to calculate the forecasts of the internal crisis in the educational institution, as a subject of market relations, existing forecasts from authoritative sources are used. Thus, the inflation forecast, which affects the cost of borrowed capital and makes it possible to identify the internal financing crisis, can be taken from the forecasts of the World Bank or from the forecasts of the International Monetary Fund.

The forecasting of all the above indicators is based on regression-correlation models, with additional consideration of the impact of other forecasts, which are irregular sources of the crisis. In general, the model for forecasting indicators has the form:

$$
P_{t}^{k}=G\left(F\left(P_{t-1}^{k}, E_{t}^{r}\right), E_{t}^{i}\right)
$$

where $P_{t}^{i}$ - forecast of the k-th indicator of the internal crisis in the $\mathrm{t}$-th period;

$G$-a function that makes adjustments for factors that cannot be taken into account in the correlation-regression model;

$F$ - a function that reflects the dependence obtained by approximating the correlationregression model;

$P_{t-1}^{i}-$ the value of the i-th indicator of the internal crisis in the t-1st period;
$E_{t}^{r}$ - the set of factors that are related to the indicator and the relationship with which can be established by correlation and regression analysis;

$E_{t}^{i}$-many external factors that are related to the indicator, but due to the lack of sufficient statistics can not be included in the correlationregression model.

Therefore, when developing a system of indicators for forecasting the internal crisis, first with the help of correlation-regression analysis, an approximation of the studied dependence is carried out. Then the resulting model is supplemented with clarifications that take into account the influence of other factors, primarily changes in the life cycle of the institution and the educational services it offers. The simulation model for forecasting indicators of the internal crisis of the educational institution as a subject of market relations makes it possible to calculate medium-term forecasts of indicators, further analysis of which using the previously described model to analyze trends in a balanced scorecard provides whether the forecast dynamics institution positive or negative. The presence of negative trends indicates the possibility of a crisis. In addition, this simulation model can be used to test crisis management scenarios and assess school bottlenecks. The method of selection of factors can take into account the 


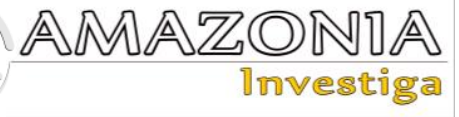

narrow months of the school and build scenarios for its development in a crisis.

When forecasting external crises that affect the educational institution as a subject of market relations, the main direction of research is forecasting the market of educational services. After all, all local crises in the external environment, which develop in the country's economy, eventually manifest themselves as a crisis in the real sector, when demand for services falls. The fundamental difference from the point of view of an educational institution as a subject of market relations is only whether the crisis is global, ie the whole real sector of the economy is involved, or the crisis is sectoral, ie it is observed only in a particular industry.

From the point of view of the relationship between the educational institution, as an economic entity and the external environment, the main thing is the implementation of educational services. The economic crisis is manifested as a general decline in economic activity, which ultimately affects the decline in demand for educational services of the institution. Therefore, the main direction of crisis forecasting is forecasting the volume of demand for its further analysis. In addition, it is proposed to forecast certain indicators of the probability of various types of external crisis, which can be used as additional grounds for analysis and development of measures for the development of the educational institution as a subject of market relations in a crisis.

The analysis of trends in the market of educational services is proposed to be carried out by correlation-regression analysis, with several strata. For the formation of strata, it is proposed to use the method of clustering k-means, which forms the strata of markets with similar characteristics.

\section{Results and Discussion}

In order to further determine the strata of the markets of educational services, it is proposed to use such characteristics as the type of educational services, the quality of educational services, the price category, etc. Thus, for the University "A", the following characteristics are set when implementing clustering:

type of educational program; appointment; volume by term of study;

The cost of the educational program.

Analysis of actual data on sales of educational services revealed the best distances between cluster centers are achieved when divided into four clusters. As a result, the market penalties are shown in Table2.

Table 2.

Market losses in forecasting the market for educational services of the University " $A$ "

\begin{tabular}{|c|c|c|c|c|}
\hline Characteristic & Cost 1 & Cost 2 & Cost 3 & Cost 4 \\
\hline $\begin{array}{l}\text { Type of educational } \\
\text { program }\end{array}$ & $\begin{array}{l}\text { Ensuring } \\
\text { practice }\end{array}$ & Ensuring practice & $\begin{array}{l}\text { Laboratory } \\
\text { equipment }\end{array}$ & $\begin{array}{l}\text { Laboratory } \\
\text { equipment }\end{array}$ \\
\hline Appointment & Humanities & Humanities & Sciences & Sciences \\
\hline $\begin{array}{l}\text { Volume by term of } \\
\text { study }\end{array}$ & $\begin{array}{l}\text { more than } 2 \\
\text { years }\end{array}$ & up to 2 years & $\begin{array}{l}\text { more than } 2.5 \\
\text { years }\end{array}$ & up to 2.5 years \\
\hline Cost & $\begin{array}{l}\text { more than } 1.5 \\
\text { thousand } \\
\text { dollars USA }\end{array}$ & $\begin{array}{l}\text { less than } 1.5 \\
\text { thousand } \\
\text { dollars USA }\end{array}$ & $\begin{array}{l}\text { more than } 2.5 \\
\text { thousand dollars } \\
\text { USA }\end{array}$ & $\begin{array}{l}\text { less than } 2.5 \\
\text { thousand } \\
\text { dollars. USA }\end{array}$ \\
\hline
\end{tabular}

Source: own research

Forecasting the volume of the market for educational services of University "A", which is based on the development of related industries and their impact on each important market strata for the university, allowed to establish that in
2022 the deterioration of educational services is expected for almost all strata except the first, the volume of sales of which is expected almost unchanged are shown in Figure 1. 


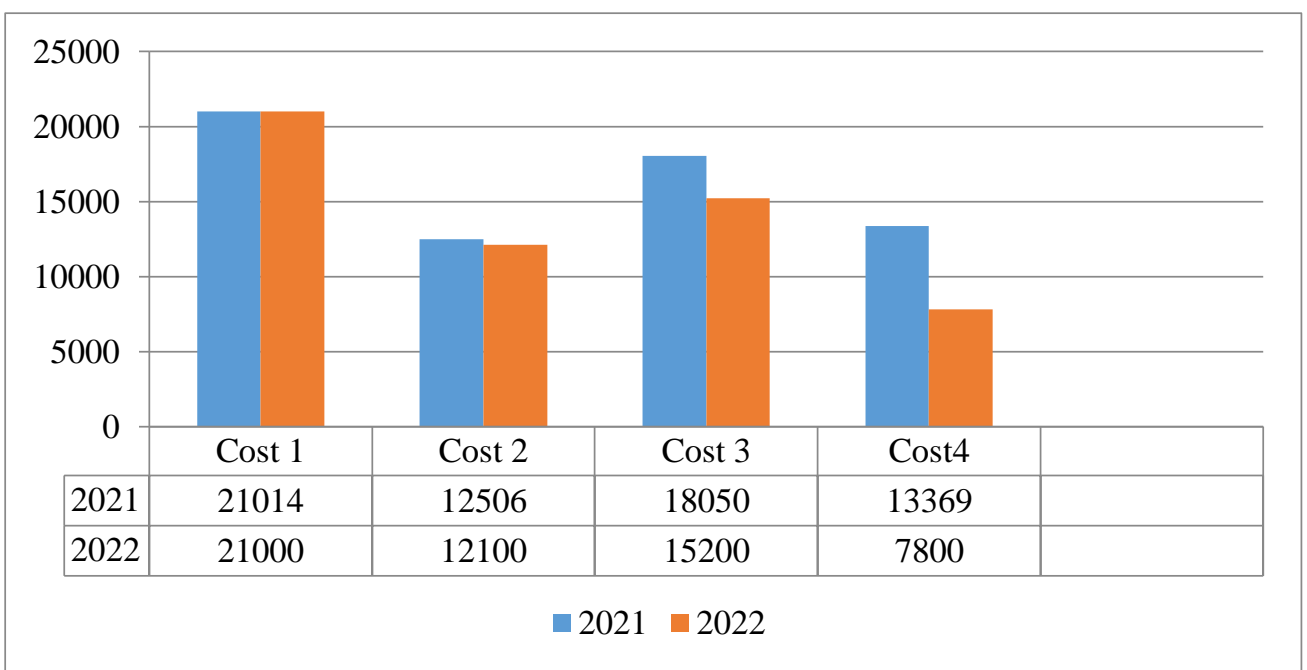

Figure 1. The results of forecasting the implementation of educational services of the University "A" at market rates.

Source: own research.

It is most appropriate to predict the global economic crisis by analyzing economic cycles. It is proposed to forecast the global economic crisis as falling into the lower phase of the waves of economic cycles or the coincidence of several such states, which exacerbates the crisis. Of the most studied economic cycles, it is proposed to consider four:

Kitchin cycles (2-4 years), which reflect the delays in the response of manufacturing enterprises to overproduction of goods;

Juglar cycles (7-10 years), which reflect the delays between inflows and outflows of investment capital;

Kuznets' rhythms (15-29 years), which reflect demographic fluctuations;

long waves of Kondratiev (50-60 years), which reflect the impact of scientific and technological progress and changes in the structure of production.

To predict economic cycles, it is proposed to assume that in general the development of the economy has a smooth trend, and deviations from the straight line are due to either economic cycles or unforeseen events, such as war. As an indicator that characterizes the state of the economy as a whole, the volume of gross domestic product is proposed. To take into account economic cycles, it is advisable to use the Holt-Winters method (Peters, 2000):

$$
G D P_{t+p}=\left(\overline{G D P}_{t}+p \cdot Z_{t}^{L}\right) S,
$$

where $G D P_{t+p}-$ GDP forecast for p periods;
$\overline{G D P}_{t}$-exponentially smoothed value of GDP;

$p$ - the number of the period for which the forecast is made;

$Z_{t}^{L}$-trend value for the last period;

$S$ - seasonality ratio for the same period in the last season.

The Holt-Winters forecast can be used for all types of economic cycles, changing the smoothing factor, which depends on the length of the economic cycle.

It is proposed to forecast sectoral economic crises through the analysis of the possibilities of qualitative jumps and the analysis of the consequences of local crises in other industries.

The forecast of qualitative leaps is made by formalizing expert assessments of the current situation in the industry and research on the improvement of educational services and educational technologies used in the field to which the educational institution belongs. The forecast of qualitative jumps is carried out by means of model:

$Q=\max \left(\frac{v^{S} \sum_{e} w_{e}^{S} S_{e}}{6}, \frac{v^{T} \sum_{e} w_{e}^{T} T_{e}}{6}, \frac{v^{M} \sum_{e} w_{e}^{M} M_{e}}{5}\right)$,

where $Q$ - forecast of qualitative jumps that may provoke a crisis in the educational institution as a subject of market relations; 


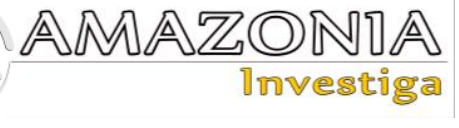

$v^{S}$ - the share of the results of the educational

institution as a subject of market relations, which depends on the qualitative leaps in the field of substitution services;

$v^{T}$ - the share of the results of the educational institution, as a subject of market relations, which depends on the qualitative leaps in the field of educational technologies;

$v^{M}$ - the share of the results of the educational institution as a subject of market relations, which depends on the qualitative leaps in the field of educational services;

$w_{e}^{S}$ - the importance of the e-th expert in the analysis of the development of substitute services that can replace the educational services of the educational institution;

$w_{e}^{T}$ - the importance of the e-th expert in the analysis of the development of educational technologies used in the educational institution;
$w_{e}^{M}$ - the importance of the e-th expert in analyzing the development of marketing communications that may affect the educational institution as a subject of market relations;

$S_{e}$ - forecast of the e-expert on the possibility of substitution services;

$T_{e}$-forecast of the e-th expert on the possibility of alternative educational technologies;

$M_{e}$-forecast of the e-th expert on the possibility of alternative marketing communications.

Of all the areas of assessing the qualitative leaps that can cause a crisis, it is enough to choose the one that is most threatened to assess the strength of the crisis, but to further develop measures to develop the school as a subject of market relations, the crisis requires all forecasts. Quantitative and qualitative assessments provided by experts on the possibility of qualitative changes that pose a threat of crisis are given in table. 3 .

Table 3.

Template of expert opinions on the possibility of quality jumps.

\begin{tabular}{lll}
\hline Indicators & Expert opinion & $\begin{array}{l}\text { Quantitative } \\
\text { assessment }\end{array}$ \\
\hline & Impossible in a strategic perspective & 0 \\
Possibility of substitution services with & Maybe in 1-2 years & 1 \\
significantly better characteristics & Will appear in 1-2 years & 3 \\
& They already exist & 6 \\
The possibility of the emergence of & Impossible in a strategic perspective & 0 \\
educational technologies with & Maybe in 1-2 years & 1 \\
significantly better characteristics & Will appear in 1-2 years & 3 \\
& They already exist & 6 \\
Possibility of changes in marketing & Impossible in a strategic perspective & 0 \\
communications & Maybe in 1-2 years & 1 \\
& Will appear in 1-2 years & 2 \\
\hline
\end{tabular}

Source: own research

According to experts, at University "A" there is a threat of qualitative leaps in the field of educational technologies, namely the introduction by competitors of more innovative approaches to educational processes, which significantly improve the characteristics of educational programs.
Thus, the above-mentioned measures to develop a system for forecasting internal and external crises of the educational institution, as a subject of market relations, are carried out according to the scheme are shown in Figure 2. 


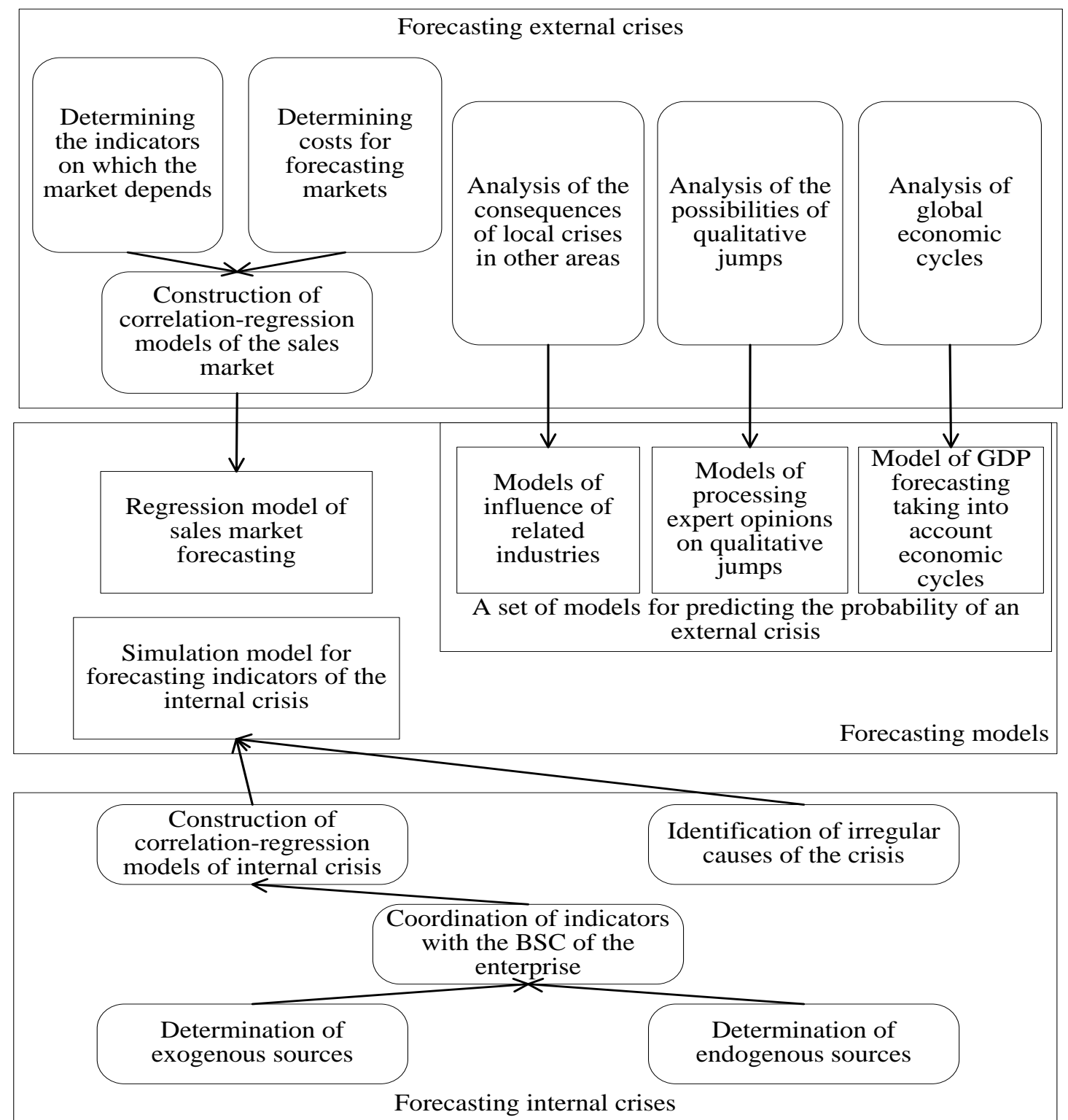

Figure 2. The sequence of development of the crisis forecasting system in the management of the development of the educational institution as a subject of market relations.

Source: own research

Approbation of the proposed approach to forecasting crisis phenomena in the management of an educational institution as a subject of market relations at a Ukrainian university proves the feasibility of combined forecasting of internal and external crises and provides the educational institution with grounds for further development strategy in economic instability.

\section{Conclusions}

It is established that in solving the problem of managing the development of an educational institution as a subject of market relations, one of the main tasks is to ensure the timeliness and accuracy of forecasting crisis phenomena. A timely crisis gives the school a competitive advantage and additional opportunities for development, while the onset of a crisis that the school, as a subject of market relations, did not expect, threatens its existence.

It is substantiated that depending on the primary source of the crisis, the forecasting of internal and external crises differs. Crisis forecasting for an educational institution consists of two directions - forecasting external crises, how they affect it, and forecasting internal crises of an educational institution, as a subject of market relations.

It is proposed to forecast the market of educational services as the main direction of research when forecasting external crises that 


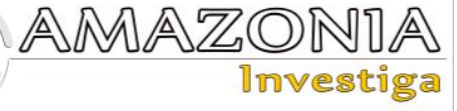

affect the educational institution as a subject of market relations. After all, all the crisis phenomena in the external environment, which are developing in the country's economy, eventually manifest themselves as a crisis in the real sector, when the demand for services falls.

To forecast internal crises at the educational institution, as a subject of market relations, it is proposed to create a system of indicators, depending on the forecasts of deterioration or improvement of which the probability of a crisis is estimated. The system of indicators is based on the principles of building a balanced system of indicators taking into account the characteristics of Ukrainian educational institutions, especially higher education institutions.

It is proposed to carry out a combined forecasting of internal and external crises, which provides the educational institution, as a subject of market relations, the basis for further development of development strategy in a crisis. The proposed models and methods are a scientific and methodological approach to forecasting crisis phenomena in managing the development of the educational institution as a subject of market relations, which is based on taking into account the characteristics of internal and external crises that may threaten it. The use of this approach in the educational institution, as a subject of market relations, makes it possible to identify the threat of various types of crisis phenomena and assess the impact of the crisis on the forecast of its educational services.

\section{Bibliographic references}

Aleksandrova, O., Hroznyi, I., Vinnikova, N., \& Chuvasova, N. (2019). Control of the quality assurance system at the modern Ukrainian university. Scientific Bulletin of National Mining- University - Economy and Management, №2, 153-162.

Altman, E. (1967). Financial Ratios, Discriminant Analysis and the Prediction of Corporate Bankruptcy. Journal of Finance, 9, 589-609.

Belay, S.V. (2015). Mechanism of state forecasting of crisis phenomena of socioeconomic nature. Investments: practice and experience, 6, 122-127. URL http://www.investplan.com.ua/?op=1\&z=43 $39 \& \mathrm{i}=24$

Das, T.K., \& Teng, B.S. (1999). Managing risks in strategic alliances. Academy of Management Executive, 13(4), 50-62.

de Haan, J., Fang, Y., \& Jing, Z. (2020). Does the risk on banks' balance sheets predict banking crises? New evidence for developing countries. International Review of Economics \& Finance, Vol 68, 254-268, https://doi.org/10.1016/j.iref.2020.03.013.

Espinosa-Vega, M.A., \& Russell, S. (2020). Interconnectedness, systemic crises, and recessions. Latin American Journal of Central Banking, 1(1-4), 100008, https://doi.org/10.1016/j.latcb.2020.100008.

Floricel, S., \& Ibanescu, M. (2008). Using R\&D portfolio management to deal with dynamic risk. R and D Management, 38(5), 452-467. http://dx.doi.org/10.1111/j.14679310.2008.00535.x

Grishchenko, I.M (2014). Professional education in the system of economic research: a monograph. K.: Gramota, 384.

Holm, T., Vuorisalo, T., \& Sammalisto, K. (2015). Integrated management systems for enhancing education for sustainable development in universities: a memetic approach. Journal of Cleaner Production, 106 , 155-163, https://doi.org/10.1016/j.jclepro.2014.03.048

Huber, M. (2011). The Risk University: Risk identification at higher education institutions in England. London: School of Economics and Political Science, 21.

Huber, M., \& Rothstein, H. (2013). The risk organisation: Or how organisations reconcile themselves to failure. Journal of Risk Research, 16(6), 651-675. http://dx.doi.org/10.1080/13669877.2012.76 1276

Kulakovskaya, T.A (2014). Methodical approaches to the analysis and forecasting of the crisis of enterprises. Economics of food industry, 3, 12-17. URL https://fie.onaft.edu.ua/uk/site/archives

Lin, J. (2021). Design of enterprise financial early warning model based on complex embedded system. Microprocessors and Microsystems, $\quad 80, \quad 103532$, https://doi.org/10.1016/j.micpro.2020.10353 2.

Lukmanova, I., \& Yaskova, N. (2016). Hidden Reserves of Post-Crisis Development of Construction Industry. Procedia Engineering, 165 , 1293-1299, https://doi.org/10.1016/j.proeng.2016.11.853

Makarenko, I.P (2008). Methodological problems of macroeconomic forecasting. Scientific and technical information, 4, 16-20.

Orlovskaya, N.O (2012). Economic crises: analysis and forecasting taking into account the coincidence of cycles of different periodicity. Scientific works of NDFI, 2, 31-36. 
Peters, E. (2000). Chaos and order in the capital markets. A new analytical view of cycles, prices and market variability. M.: Mir, 333.

Prokopenko, R.V (2015). Substantiation of methodology of modeling of diversification of foreign economic interactions of Ukraine. Economics and Management: Scientific Journal. Kyiv: Europe. University, 3 (67), $14-21$ URL https://e-u.edu.ua/journal/556.pdf

Raban, C., \& Turner, L.C. (2006). Quality risk management. Modernising the architecture of quality assurance. Perspectives: Policy and Practice in Higher Education, 10(2), 39-44. http://dx.doi.org/10.1080/136031006006445 22

Sapayeva, L.S (2013). Global forecasts and crisis society. Bulletin of the Odessa National University. Sociology and political science, 18, 2 (2), 11-17.

Shulgina, O.V (2011). Model of forecasting the crisis in the economy of Ukraine. Scientific notes of the National University "Ostroh Academy". Series: Economics, 18, 627-634.

Stepaniuk, N.A (2013). Forecasting crisis phenomena in the economy. Scientific notes National University "Ostroh Academy". Economy, 23, 103-107.

Syreyshchikova, N.V., Pimenov, D.Yu., Mikolajczyk, T., \& Moldovan, L. (2020). Development of a Risk Management Technique in Strategic Planning of Universities. Case study of a Polytechnical
Institute, Procedia Manufacturing, 46, 256-262, https://doi.org/10.1016/j.promfg.2020.03.03 8.

Tarasova, H., Zaharov, S., Vereskun, M., \& Kolosok, V. (2019). Preventive anticrisis strategy for development of industrial enterprise. Independent Journal of Management \& Production, 10(5), 14051420. https://doi.org/10.14807/ijmp.v10i5.8 90

Vasiliev, O.V., \& Goy, V.V. (2016). Methods of forecasting the financial stability of the enterprise in a crisis. Scientific Bulletin of the International Humanities University. Series: Economics and Management, 17, 116-121.

Wang, A., \& Pitsis, T.S. (2020). Identifying the antecedents of megaproject crises in China. International Journal of Project Management, 38(6), 2327-339, https://doi.org/10.1016/j.ijproman.2019.05.0 03.

Zhang, L., \& Wang, L. (2016). Risk application research on risk warning mechanism in organizational crisis management - taking Vanke Real Estate Co. Ltd., as an example. Chaos, Solitons \& Fractals, 89, 373-380, https://doi.org/10.1016/j.chaos.2016.01.019.

Zhyvotenko, V.O. (2014). Features of forming a system of indicators of development of crisis phenomena in the enterprise. Problems and prospects of business development, 2(2), 162-166. 